\title{
Chapter 6 \\ What Is the Nature of Christian Love? \\ Homo Amans and Revolutionary Altruism
}

\author{
Rebekka A. Klein
}

\begin{abstract}
The attempt to explore human beings transdisciplinarily as beings of love can contribute to a more realistic anthropology, with an increased practical relevance for science and research. On the other hand, with its holistic orientation towards the whole person, it leads to an improper standardization of scientific research results. In order to avoid the problems associated with the holistic study of man as Homo amans, this article therefore reverses the perspective. Fundamentally, the nature of love is not discussed anthropologically on the basis of an examination of human nature and its altruism or egoism, but on the basis of the phenomenon of love in its ambivalence. Following Kierkegaard's phenomenology of love, the article shows that love cannot be clearly distinguished from selfish acts without the reference of interpersonal relationships with a "third party." In the Christian perspective, God is such a "third party," who makes our fellow human beings recognizable to us as neighbors of God and enables us to behave in the spirit of love. Christian love of neighbor is therefore an example of the revolutionary, socially transformative dynamics of love.
\end{abstract}

\subsection{Introduction}

"A person can flourish only by seeking the common good, by seeking the good for oneself and others."

"Economics should foster the human well-being."

These quotes from the outline of the Homo amans project are significant for the aspirations and hopes that our society and culture ascribe to science in the present day. They remind us that science and ethics are subject to intense questioning these days in terms of their usefulness and real-world orientation. This questioning of science as a whole represents a major trend in society and politics as well as in the

\footnotetext{
R. A. Klein $(\bowtie)$

Ruhr-Universität Bochum, Bochum, Germany

e-mail: rebekka.klein@rub.de
} 
contemporary philosophy of science. In this respect, it is no longer regarded as sufficient for scientific knowledge and interdisciplinary research to seek the truth or find out facts and figures concerning a certain subject or question of theory. Rather, the two processes are brought together to make a substantial contribution to solving the real-world problems of our society (Mittelstraß 1982; Klein 2017). One slogan that is very well known in this context is "science into society," which is currently very common in the design of new research projects and proposals in so-called hard sciences.

In order to contribute to solving real-world problems - which can be said to be the main goal of scientific research in the twenty-first century - it is suggested that science should take a more holistic perspective, not submerging itself in the production of academic and scholarly knowledge, but rather it should develop concrete insights, which can actually be proven to be orientational and useful in our everyday lives (Nowotny 1997, 1999; Nowotny et al. 2001). A viable way to achieve this goal, which has evolved in recent decades, is to pursue science in a transdisciplinary manner, i.e., by integrating different scholarly and disciplinary approaches, methods, and perspectives into a more comprehensive and unifying scientific endeavor (Hirsch-Hadorn et al. 2008; Mittelstraß 2003). The rationale behind this trend is the idea that science has the power to influence and transform real life but that it can only actualize this power when it becomes holistic again - as with premodern scientific knowledge practices, for example. Consequently, a trend has also resurfaced towards the antique and premodern traditions of wisdom and knowledge.

Likewise, the Homo amans project seeks to develop the idea that science should serve the common good of society and help to solve real-world problems. In the outline of the Project it is argued that economics must foster human flourishing instead of merely finding out the truth about human nature (as it is). What is implied here is that science has to prove the anthropological, psychological, societal and political usefulness, pragmatic and ethical impact of its insights, rather than merely safeguarding the correct methodological fabrication of scientific facts. Thus, transdisciplinary and holistic research prospects also represent a shift towards greater commitment from scientists to ethical and social change, and also to political and societal interests. A political interest which could be seen to lie behind this focus on human flourishing in current science, especially in economics and ethics, is the concern that people should not be broken by the wheels of late-modern capitalist working conditions; becoming mentally or physically sick from exhaustion, for example. Thus, the focus on human well-being as the latest goal to be served by the economy represents a political resource, transforming contemporary society for the better. A concrete example of the increasing relevance of this issue can be seen in the public discussion of the retirement of German politician Andrea Nahles in June 2019 who gave up her leading position in the social democratic party after severe infighting. Responding to this incident, a journalist from the German newspaper DIE ZEIT claimed that the exercise of power in politics, which was formerly a domain of masculine virtues and cold-blooded heroism, should become more humane and solidary (Peitz 2019). 
A second point of reference in explaining society's current interest in human flourishing is the attempt to interpret it as a response to the nihilisms of late modernity. As theologian Miroslav Volf has argued in his book on this topic, there are two nihilisms in late modernity which reinforce each other: the passive nihilism of fundamentalists and the active nihilism of libertarians (Volf 2015, p. 200f). Both have in common an unsustainable end for our lives. The passive nihilism of religious world-deniers and world-destroyers offers a life with strong values and a transcendent foundation which imbues the order of life with "weight" and meaning. This is illustrated, for example, in the attractiveness for young Westerners of terrorist organizations such as the Islamic State. Here, such a strict and stable order of meaning can be a welcome alternative to the active nihilism practiced in market-driven globalization movements of late modernity. The latter have given rise to a character type which Volf calls "free spirits," i.e. consumerists for whom nothing matters with any sort of profundity, or who lack a constancy of meaning. Their nihilism consists in the willingness to fight "for the pleasures and comforts of their way of life" (Volf 2015 , p. 201) making the realm of values ultimately arbitrary and insignificant. According to Volf, the plea for human flourishing in the present is therefore to be seen as an attempt to find a third way which - as he suggests - is the great challenge of our time (Volf 2015, p. 201).

Thus, current endeavors to reorient science and research towards human wellbeing as a whole, stand on the horizon of a broader development in late modern culture. A number of consequences follow from this reorientation of science which can be summarized as follows: firstly, pressure to solve overall societal problems and to present an all-inclusive solution to them means that scientists are motivated to develop an integrative and overly harmonious picture of human society which tends to make the solutions they are studying more plausible and approachable. Consequently, they are inclined to disregard the fractures and ambivalences of certain phenomena or theories under investigation, for in giving attention to such fractures they would make their own account more vulnerable and less efficient. Secondly, transdisciplinary research projects ultimately create transformative knowledge rather than picturing and reproducing the world as it is. As convincing as this endeavor may be in times of postmodernist relativism, constructivism, and perspectivist visions of truth, it nonetheless shifts the focus of science away from objectivity and independence of real-world matters, and reshapes its work into a kind of service enterprise (which is, I believe, problematic in the long run). Thirdly, scientists who take a transdisciplinary perspective and attempt to solve real-world problems of a holistic nature are in danger of becoming "do-gooders" (Weltverbesserer, in German) when participating in the scientific process. This means that they might leave the "cool mood" of science and philosophy and become over-engaged campaigners.

Let us now turn to the Homo amans project. The initiators of this project would probably resist my emphasis on the major shift from investigating human nature (as it is) to studying human flourishing (as it can be advanced by society and science). They would certainly argue that such predestined flourishing refers directly to human nature (as it is) and is not to be separated from it. This is rational because 
they argue from an approach of virtue ethics. In this approach, flourishing and the nature of human beings are essentially the same thing. Hence, human beings always become what they should be, and the study of human nature is the study of human beings' final destiny.

Now, my aim in this regard is not to downgrade or devalue the perspective of the initiators of the Homo amans project in any way. Rather, I want to create a productive contrast, applying my own approach and experience (Klein 2011) from a transdisciplinary perspective in order to shed some light on aspects which may not have been given enough attention in the outline of the Homo amans project. This means that my goal is to challenge and, ultimately, complement the project's perspective, as well as to describe and to explore the limits and problems inherent in the argument that is presented here.

My discussion is divided into two main parts as follows: sections two and three of my chapter critique and respond to the Homo amans model as given in the initiators' outline. I will focus on the opposition of Homo economicus and Homo amans, critically exploring the holistic nature of anthropological models in general. Finally, I will contrast the understanding of the virtue of love in Homo amans, taking a phenomenological approach that encompasses ambivalence as well as the failure of human love. The second main part of the paper will then develop and elaborate upon my own understanding of the nature of love. It will effectively present a reversal of perspective by, firstly, seeking to understand the nature of love and then questioning the nature of human beings on the basis of this understanding. I will argue that this is exactly the right order of thought if we truly want to adopt a Christian perspective on the topic. In section four, this thesis is elaborated further by following the thought of the Danish philosopher and theologian Søren Kierkegaard and his argument that a (self-)critique of love is the key to love's flourishing. Although Kierkegaard regards love as a reality of human life and not as a purely fantastical idea that belongs to some Christian people, he strongly resists the opinion that love could be exercised as a virtue of human nature itself. He defends the view that Christian love is not among the capabilities of human beings and should not be identified with the nature of human being. Instead, he argues that love is made possible by a relationship to the other as a child of God, and that it is God as a "middle term" in this relationship who liberates human beings from their narcissism and selfishness. I will provide some support for this position and, finally, I will try to give my own answer to the question of the true nature of Christian love. In the fifth section, therefore, I will argue that love is to be understood as a form of revolutionary altruism. Its revolutionary effects originate from its power to transform social relations by reshaping them from the point of view of a new reality. Here, love can be described as a central dynamic in human life that introduces radically new perspectives and social practices. Beyond Kierkegaard's focus on the presence of God, the revolutionary nature of love can be seen in the interruption of the normality of social relation and interaction by introducing the relation to a third of universal nature into the ordinary relation of self and other. Finally, it will be shown that love is misunderstood by focussing solely on the relationality of human beings, because the understanding of love also requires an understanding of the interruption of social relations. 


\subsection{The Problems and Limitations of a Holistic Anthropological Model}

The Homo amans project attempts to collect and synthesize an assortment of developments within the study of human nature and philosophical anthropology from the past few decades. It does so in a very inspiring manner and grounds these recent advances in a philosophical anthropology of relationality. However, relational anthropology, as presented here, is mainly concerned with the dynamics of becoming human rather than the state of being human. It has the conviction that humans become what they are, in and through the relations which form and inform their lives and self-understanding. Relational anthropology, therefore, moves away from understanding human nature as an essence or core of the human being. It conceives it anew, not as a given but as a dynamic structure. This means, the nature of humans is not assumed to be the same or self-identical all the time. Rather, it develops in a certain direction out of a varied network of relationships with oneself and others. Hence, in this approach, crucial questions concerning humankind shift from the nature of human beings to the nature of their relationship with themselves and others.

In my view, it is not quite clear whether this approach and its shift of perspective has been fully acknowledged and valued in the given outline of the Homo amans project. The crux of my concern here would be the starting point of the project, which is in strict opposition to the Homo economicus model prevalent in economics and the social sciences. The outline of the project expressly refers to John Stuart Mill's definition. Homo economicus is defined as a human being capable of judging the comparative efficacy of the means for obtaining an end, as the outline paper says. Homo economicus thus refers to the mainly self-concerned utility maximizer who manifests an egotistic type of rationality in his preferences, choices, and behavior. In the outline of the project, this model of Homo economicus is taken to be a mere idea or concept, which appeared at a certain point in the history of ideas. As a result, its reality content is devalued. Furthermore, it is criticized for being too narrow to account for the full spectrum of human behavior, although no mention is made of the possibility of there being at least some truth in it as far as human beings are concerned.

In contrast, the Homo amans project, as it is outlined here, aims to introduce love and the Christian virtues of faith and hope into the picture and form a wholly new understanding of human sociality. Homo amans thus provides a fuller picture of human life and its relationality, i.e. concern for the well-being of others, for the common good, and for the crucial role given to the prevalence and protection of social norms. As appropriate and rightful as this endeavor undoubtedly is - and I have the utmost respect for it - there is an inherent danger in the strict opposition between Homo economicus and Homo amans and also, very often, in the broader discourse about changes to this model in the social sciences. When the concept of virtues and human relationality, on the one hand, is contrasted with a mistaken understanding of the human being as merely a rational utility maximizer on the other, two problems can arise from this starting point: (a) the limited but 
nonetheless existing reality content of the Homo economicus model could be marginalized and overlooked; and (b) the model of Homo amans could be taken as a full and definitive representation of the reality of human beings. In sum, the Homo amans perspective could then be implemented in the same totalitarian fashion as the other model was before.

Both points can now be seen to endanger a correct understanding of the Homo amans project because they could - perhaps not initially but later on - produce negative consequences in the continuation and building of a Homo amans anthropology. Whereas the first point mentioned above could result in the Homo amans model itself becoming ideological as it neglects and denies the reality of egotistic and self-concerned attitudes and behaviors in the study of humankind, the second point could imply a naïve bias, as with the Homo economics model previously, when taken to be the sole and exclusive model of human behavior. The first problem leads to the question of how Homo economicus and Homo amans (or human beings with egotistic and prosocial preferences) can coexist and/or interact with one another or how the second one can prevail over the first one in social interaction. The second problem leads to the question of how the concept of love can be focused and differentiated enough to discriminate between the ambivalent and multi-layered phenomenology of real-world phenomena.

To put it more succinctly, my concern is that the holism indicated in the Homo amans model could entrap and suppress the intrusions and ambivalences of sociality phenomena in real life. Therefore, what is needed here is a dual perspective involving (a) antagonizing or conflicting Homo amans with the reality of Homo economicus and (b) differentiating the inner reality of Homo amans by exploring and probing inner tensions and misunderstandings associated with love among human beings. The following sections will address the second research lacuna of the Homo amans project and the final part of this article will elaborate further on the antagonism between Homo amans and Homo economicus.

\subsection{The Focus on Virtues and the Ambivalence or Failure of Love}

The outline of the Homo amans project does not only motivate study of Homo amans by presenting it as "a viable alternative" to Homo economicus but also by pointing to the prosocial qualities of humans living a life of love. Thus, Homo amans is pictured in the project as an other-regarding, cooperative, and even altruistic being by nature. These prosocial qualities are further elaborated to constitute a phenomenology of human flourishing. However, at this point in the outline paper there is a certain changing of perspective which takes place; from the level of typifying and modeling human behavior to the level of an ethically informed phenomenology of human life. This change of perspective can be addressed by distinguishing between the terms "prosociality" and "human flourishing." 
In behavioral sciences as well as in social psychology and evolutionary studies, the term "prosociality" denotes a type of behavior which contributes to the welfare of society as a whole insofar as it increases, for example, the cooperation level of a certain group (Gintis 2003; Henrich and Henrich 2006). "Prosocial" behavior may include concrete actions of helping or benefitting others, but also punitive actions, for example, the sanctioning of social norms (Fehr and Gächter 2002). Hence, the term "prosociality" also refers to the fact that not all actions which benefit the welfare and flourishing of human societies have to be at the same time actions benefitting the welfare of concrete others. As demonstrated in the case of social sanctions, such as the "altruistic punishment" (Fehr and Gächter 2002) $)^{1}$ of norm violators and free riders, a prosocial behavior is not required to be beneficial to the other in either case. Instead, it can also contribute to the common good, for example: the enforcement of social and cooperation norms by introducing severe costs at the personal level of social interactions.

In contrast, the term "flourishing" does not refer to a certain mechanism of behavior which can be measured and observed or to an outcome-oriented approach to human action at all but to a psychological attitude or lifestyle of individuals that is seen to be balanced, resilient, and orientated towards positive emotions and wellbeing, in order to allow humanity as a whole to flourish (Keyes and Haidt 2007). Taken as a psychological term, it describes the optimal functioning of human beings or their ability to live their lives well - even in the face of suffering and frailty (Fowers 2017). The term has recently become prominent in the context of positive psychology but it can be traced back to the antique Aristotelian concept of eudaimonia which means striving to live an intrinsically good life (Aristotle 2014).

As Miroslav Volf has shown in his book Flourishing, a good life has to be understood as a life worth living viz. a meaningful life in late modernity (Volf 2015, pp. 1-26). Volf emphasizes that the turn towards flourishing points toward the fact that life has to be more than just the satisfaction of needs and the initialization of pleasures, but also has to have meaning (Volf 2015, pp. 195-206). Furthermore, he suggests that the goodness of life we are striving for should not be understood too idealistically or transcendently, but rather that flourishing requires a unity of meaningfulness, as well as the experience of pleasure and joy, in order to avoid a decline into nihilism (Volf 2015, p. 201).

Hence, the shift from the observation of prosocial behaviors to the study of human flourishing and the phenomenology of a good and meaningful life, which is taken by the proponents of the Homo amans project, is a step into an ethically informed perspective on human life as well as a step into developing a holistic, instead of a fractional, perspective. In this shift of perspective, what is called the phenomenological constitution of Homo amans is made understandable by elaborating on the inner reality and differentiation of human beings' capabilities and virtues. The latter are focused on the triadic interrelation of three core virtues,

\footnotetext{
${ }^{1}$ For a critical commentary on the experimental studies on altruistic punishment see Klein (2011) as well as the article published together with Christine Clavien: Clavien and Klein (2010).
} 
which are assumed to be inseparable. Thus, the initiators of this project express their conviction that the inner reality of Homo amans can be made understandable by discriminating between three basic capabilities of the human being: love, hope, and faith. These virtues can be traced back to the biblical tradition and to the epistles of Saint Paul, who wrote in 1 Corinthians 13 that these three are the basic virtues of a Christian community, but that love is the greatest among them. In his epistle, the apostle makes it quite clear that neither the gifts of charismatic speech nor wisdom nor knowledge can build up Christian community as this is done by acts of love.

In the reading of this tradition by the proponents of the Homo amans project, faith represents the quest for meaning in human life. Hope reflects the universal human desire for a future, and love (taken as being the primary virtue) grounds all human capabilities and virtues in relation to other human beings, making it quite clear that human beings are social or rather prosocial beings. With regard to the primacy of love, the initiators of the Homo amans project argue that love is a feminine virtue that might lead to a complementary rather than exclusive understanding of human nature. This then stands in contrast to the masculine virtues, which are characterized as being more or less anti-relational or egotistic.

From the outline paper, it follows that the virtue of love is somehow seen to prevail over faith and hope because (a) it is of a fundamental nature, pointing towards the basic relationality ${ }^{2}$ of human beings and (b) it relates to secular anthropology more easily because the core relation inherent in love is taken to be primarily interpersonal and not divine, given that God is not the main object of love but is certainly the main object of faith and hope. I would like to challenge the last thesis in particular, as we will see later.

For now, I want to stress another point and to question whether the virtue of love, in a very common theological fashion, is presented in an overly positivistic manner by the Homo amans project outlined so far. To address my suspicion, I would like to pose some exploratory questions concerning the nature of love and its visibility and appearance in human life: Where do we find love in our lives and can it actually be equated to the prosocial behaviors and attitudes of cooperation and altruism? Is love grounded in a feeling, or is it grounded in a rational choice made by us? Is love a capability and among the properties of human life, or rather is it a phenomenon of contingent appearance? Is love the solution, or key, to human flourishing, or is it a challenge that we do not normally master but which always proves to be a milestone for failure in our lives?

These questions suggest that it is not so clear or obvious what love is and which role it plays in our life. Furthermore, it can be said that the longing for love as well as the desire for bonding, for reliable commitment and rootedness, is a kind of child of the spirit of our age, and I think this should also be taken into account when we address the problem of exploring the possibilities and limits of an orientation towards a loving human being. Human beings have become increasingly uprooted

\footnotetext{
${ }^{2}$ See this claim regarding St. Paul's preoccupation with love also in Schnelle (1999, p. 84).
} 
and separated from their original bonds in late modern societies since the industrial revolution and late-capitalist globalization movements. Hence, an orientation towards relationality as well as a strengthening of other-regarding attitudes and behaviors seem to be the solution to the pressing problem of growing anonymity and atomization of the human being in a liquid modernity with fluid identities (as, for example, sociologist Zygmunt Bauman [2000] has argued). Not for nothing, then, recent studies in science - for example, the social neurosciences and economics of empathy and care - have been inaugurated and conducted on the grounds that we need to develop mental training in empathy and other caring attitudes, particularly in a globalized world where we are confronted with "the stranger" every day. ${ }^{3}$ A better understanding of the neural mechanisms of empathy and care could thus help to better position us in the advancement of human flourishing.

These remarks are given to indicate that the quest for an examination of Homo amans is in no way a timeless or contextless project. Rather, the study of Homo amans can be seen as an indicator of a growing uncertainty about formerly selfevident phenomena in the era of globalization. Because traditional means of social bonding and human relationality have been broken so dramatically and with such intensity in late modern times, people long for a deeper understanding and maybe also for a restoration, or for a new configuration, of these basics of human flourishing. Seen in the context of the current agenda, a virtue approach to Homo amans which is mainly elaborated in Neo-Aristotelian terminology might overlook the opportunity to reflect on this current context agenda, and, therefore, could create a superficial impression of a romanticized fairy-tale like world instead. But I think that this is in no way intended in the Homo amans project.

The following thoughts should not, therefore, be understood so much as a critique but as a continuation of the differentiation process of the Homo amans project. The differentiation achieved by discriminating between love, faith, and hope must be opened out into a differentiation process of the inner reality of love. This inner difference of love will continue to be explored in the next section with reference to the work of Søren Kierkegaard.

\subsection{Kierkegaard: A (Self-)Critique of Love as the Key to Love's Flourishing}

In his later work, gathering together a collection of upbuilding discourses, Søren Kierkegaard wrote a book on the realness and actuality of Christian love, entitled The Works of Love ([1847] 1995). He did so because he was concerned that love

\footnotetext{
${ }^{3}$ See "Ein mentales Training, um toleranter Weltbürger zu werden," Interview with Prof. Tania Singer, Director at the Max-Planck-Institute for Human Cognitive and Brain Sciences, 7. Oct. 2017, https://www.mpg.de/11514867/interview-singer-neue-meditationstechnik-fuer-empathie (accessed 26 Aug. 2019).
} 
should not be taken as an idea but as a reality, not as an ethical ideal but as concrete work that can actually be done. At the same time, in his book, Kierkegaard directly addresses the problem that love cannot easily be discriminated from other actions and that it has a certain "invisibility" among human affairs. He writes at the beginning of his book: "There is no work, not one single one, not even the best, about which we can unconditionally dare to say: The one who does this unconditionally demonstrates love by it" (Kierkegaard 1995, p. 13).

This means that love is not a phenomenon which can be recognized easily and that there is no proof or demonstration of love which safeguards its existence. Love is not a certain type of action or a stable character trait at all. Rather, Kierkegaard determines the relation of love and action as follows: "It depends on how the work is done" (Kierkegaard 1995, p. 13). Obviously, the view that love is a general trait of human persons or actions is not helpful but only obfuscates the study of its phenomenality. Kierkegaard emphasizes that the reality of love is, let us say, more complicated. Its study requires a special form of phenomenology which Kierkegaard then aims to develop throughout his book.

In recent years, there has been an extended discussion about whether Kierkegaard's book, The Works of Love, and the phenomenology of love that is developed in it, can be considered to be ethical in nature. In it, Kierkegaard himself polemicizes against certain strands of modern moral philosophy. Arguments, therefore, have been put forward to suggest that it seeks to engender ethical wisdom (Grøn 1998, pp. 358-68) and that it can even be interpreted as the pursuit of love as virtue. ${ }^{4}$ On the other hand, there have also been suggestions that Kierkegaard's ethical considerations in this book are built on a theology of sin and that he is sceptical about seeing love as a meritorious action (Welz 2007). Hence, Kierkegaard's intention could not have been to build an ethical theory of human virtues. Against the view that he is not a virtue theorist, it has been argued that there is some evidence in his book that he also thinks about the constitution of the author of loving action (Lippitt 2013, p. 7). Or at least, that he sees love as "a divinely inspired potential that we humans are required to actualize" (Krishek 2017, pp. 3-15, esp. pp. 3-4). It has also been pointed out that he argues that "emotion-virtues," understood as ways of seeing the other, can be cultivated in Christian faith. ${ }^{5}$

A more moderate view regarding this debate is taken by Claudia Welz when she argues that "Works of Love can be termed as a 'virtue ethics' only in a restricted sense", because in Kierkegaard's view "it is not the human agent himself who naturally develops the virtue of love, nor does (s)he receive a supernatural virtue for personal use" (Welz 2007, p. 272). Rather, love could be actualized by the human being only "by acting in the spirit of God's love" (Welz 2007, p. 281). As Welz

\footnotetext{
${ }^{4}$ An ethical theorist who has put this thesis forward in many publications is Robert C. Roberts. See Roberts (1995, pp. 142-66; 2008, pp. 72-92, and many more).

${ }^{5}$ Compare the argument that virtuists like Kierkegaard are committed to upbuilding and ethical education, including a formation of proper concerns and dispositions of emotion, in Lippitt (2017). The approach to Kierkegaard as an emotion-virtuist is also elaborated in Welz (2007); Evans (2008).
} 
argues, the relation of the human being to the other is built up by the reality of God's love alone.

Against the backdrop of this debate, one's attention should be turned to the phenomenology at stake in Works of Love. The term "phenomenology" here refers to a study of the way love comes into being and how it can be identified in its significance. In this regard, Kierkegaard emphasizes that love has a "hidden life" that we have to explore and carefully discover (Kierkegaard 1995, pp. 5-16). Very often we invariably think we already live a life of love and we err precisely because of our certainty. According to Kierkegaard, it is very important, then, to acknowledge that love is not just given to us as an inherent part of our nature that can be exercised on a whim. On the contrary, in an in-depth analysis of interpersonal relationships and social interaction, he demonstrates that we are more often confronted with the impossibilities of loving ourselves and others than with the experience of love in the true sense of the word.

Kierkegaard writes parts of his book, then, to reduce his readers to despair and release them from their certainty that love is already there in their lives. Nonetheless, on the other hand, he also aims to encourage the reader to see that love is a way to live one's life before God. According to him, it is something which can manifest in our lives although we experience all the misunderstandings, failures, and aporias that exist in human togetherness. To experience the failure of love, then, does not mean that we have to call off the realm of love and social bonding completely. For him, a self-critique of love is, in the end, the key to the flourishing of love's true nature.

By taking this position, Kierkegaard makes it possible to introduce a critical view of human sociality into the picture of love. Love is not automatically a representative of the good life prevailing under all circumstances. Love is not just a token of a certain type but is contingent in nature. The latter is made clear when Kierkegaard develops his phenomenology of love from a decidedly Christian point of view. To him, love is not only one of a kind but the only true way of living one's life in the spirit of Christian faith. In no way does this imply a glorification of the Christian way of life. Hence, Kierkegaard develops the latter stance into a self-critical attitude of modernity and Christian religion. A part of his phenomenology of love, therefore, is a critical discussion of the modern ideal of romantic love as well as the Christian denial and demonization of self-love (Lippitt 2013). Furthermore, he reviews critically the tradition of the denial of bodily love in Christianity and Western culture, and, in the light of true selflessness, questions the high esteem for seemingly altruistic and selfless behaviors celebrating a cult of the self in the other.

Kierkegaard, hereby, again resists the view that loving action is to be seen as a self-evident outcome of human nature (Kierkegaard 1995, Chapter III.A, IX 90-IX 129, pp. 91-134). His phenomenology of love is not built on the seemingly solid grounds of anthropology. Instead, it opens the door for social criticism and for a critical debate on widespread preconceptions of what love is in the Christian tradition. Through the narrowly designed contrast between human love and that of true Christian love, Kierkegaard accounts for the problem that in real life, loving 
attitudes and behaviors mostly remain ambivalent and difficult in their nature. ${ }^{6}$ In his upbuilding discourses, he argues that what true love is (or is not) can be judged neither from the object of love or its meaning to the subject, nor from the selfless outcomes of its actions, nor the spiritual versus bodily nature of love. Rather, proper love, as Christians understand the word, can only be identified in this world by acknowledging that God has put love close to us, namely, in our neighbor (Kierkegaard 1995, Chapters II.B and II.C, IX 47- IX 89, pp. 44-90). The core of concrete love, as Kierkegaard puts it, is to see others just as they are and respond accordingly. ${ }^{7}$ Hence, love is not a distant ideal that we reach out for, but is rather a daily concrete encounter with someone near to us (Kierkegaard 1995, Chapter IV, IX 147-IX 194, pp. 154-204). At the same time, however, it is exactly this concrete person whom we generally neither address nor see in the right way because we all too often account for their presence only in the horizon of selfish preferences or even narcissistic attitudes. Hence, love is needed to open our eyes, despite the fact that it is seldom found and exercised.

According to Kierkegaard, it is only the language and performativity of the Christian tradition and its way of life which gives witness to the eye-opening process and dynamic of love in our lives. It is the term, or better, the metaphor of the "neighbor" from the biblical tradition which can help to illuminate the dynamic of transformation taking place in love. The "neighbor" then serves as a middle term in all our social relationships as Kierkegaard continually seeks to emphasize (Kierkegaard 1995, Chapter II.B, IX 60, p. 58). The other being seen as the neighbor enters social relationships as a qualifying dimension, transforming the dyadic relation of self and other into a social and universal one in the full sense of the term. Concretely, the neighbor stands for a different mode of seeing the other, i.e., of seeing the other as a child of God who is neither worth more nor less than me and is an equal. ${ }^{8}$ Thus, seeing others as neighbors means to acknowledge the primacy of this equality in all the inequalities and injustices of human relationships. Seeing the other as an equal child of God, therefore, helps the human being to acknowledge the nearness of love and also its practicability.

What love is and how it can be sought and found in our lives is, for Kierkegaard, clearly committed to a Christian perspective. Here, God appears not as the object of love but as a "middle term," as Kierkegaard calls it, which helps to redirect our relationships in order to make them more equal, more consistent, more solid, more responsive and concrete. Consequently, these relationships will be mediated and

\footnotetext{
${ }^{6}$ For an emphasis on the difficulty of love and the rigor of its demands, see Critchley (2012, pp. 247-52).

${ }^{7}$ This has been referred to as Kierkegaard's "paradoxical embrace of both the universal and the particular" which could form a model for the commitment in the context of multicultural societies and globalism in Veninga (2018, p. 122).

${ }^{8}$ Kierkegaard (1995, Chapter II.B, p. 60): “The neighbor is one who is equal. [...] He is your neighbor on the basis of equality with you before God, but unconditionally every person has this equality and has it unconditionally."

${ }^{9}$ Kierkegaard (1995, Chapter II.B, IX 60, p. 58): "in love for the neighbor, God is the middle term".
} 
transformed into relationships of a new kind: relationships of love. It is this new perspective and the actions resulting from it which mark the dynamic of love as a dynamic of freedom. From this perspective, Kierkegaard can address the pressing questions arising in the ethical study of human helping and other benevolent actions, such as: Are works of love driven by feelings and emotions or by rational interests? Are they self-concerned or other-concerned? Is sacrifice for the other always a form of love? Etc. To all these questions, Kierkegaard can give a clear answer, namely that the crucial criterion in this regard is whether the loving action is oriented towards the other by seeing and addressing him as a neighbor (as a fellow child of God).

In the concluding section, I will now return to the question of what the nature of love is and how it can be addressed best by a scientific approach. Following the fundamental distinctions of Kierkegaard's phenomenology, I will argue that love is not an attitude, an action, or a virtue but a central dynamic in human life which has the power to transform all social relations into prosocial ones with a tendency towards universality. The structural dynamic of love, thus, can be characterized as disruptive. Thus, I will argue, secondly, that the invoked dynamic of love is marked by a certain kind of revolutionary potential. The nature of love, then, can be found in its power of social transformation. It opens certain social practices, as well as dyadic and egotistic relationships, to change by introducing a third one which works as the initiator of a different order and establishes social bridging and prosociality. ${ }^{10}$ In the end, it will be shown that the dynamic of love will not be subsumed by social techniques aiming at human flourishing or the ethical quest for a good life, because, rather, it is of a non-conformist nature and aims at unmasking the ideological character of social techniques of human flourishing too.

\subsection{The Nature of Love and Revolutionary Altruism ${ }^{11}$}

Besides Kierkegaard who has written at length of the inner struggles of love, there remains the question posed earlier in this paper whether there is any valid content in the repudiated Homo economicus model and consequently whether there is a struggle for love to be won against the non-cooperative and egotistic behaviour of utility maximizing. In this regard, it might be interesting to note some critiques of the Homo economicus model in the field of neuroeconomics, a research approach combining experimental economics and social neuroscience (Vromen and Marchionni 2019; Glimcher et al. 2009). This newly emerging field of transdisciplinary research aims to overcome neoclassical economics and to "provide an alternative theoretical approach for predicting behaviour" (Glimcher et al. 2009, p. 7). Its major paradigms for studying human social behavior are behavioral experiments designed after the

\footnotetext{
${ }^{10}$ For a study of the role and order of the third in social philosophy, see Bedorf (2003).

${ }^{11}$ Parts of this section have already been published in: Klein (2012).
} 
paradigms of game theory, as for example the trust game, the dictator game, and the third-party punishment game etc. (Gintis 2000). Neuroeconomics does not simply take leave of the model of Homo economicus. Rather, it takes egoism to be a continuing challenge to the prosocial orientation of altruistic and cooperative human beings. Hence, the research question posed here is how altruism ${ }^{12}$ and prosocial behaviors can prevail over Homo economicus? (Fehr and Gächter 2002; Fehr and Rosenbach 2003). ${ }^{13}$ A special focus in the field of prosociality is placed on the study of norm enforcement.

Several experimental studies on cooperation and prosociality in economics have shown that altruistic punishment plays a key role in understanding the evolution of norm enforcement in human societies. ${ }^{14}$ Altruistic punishment does not directly benefit the welfare of an individual person, but society as a whole. Therefore, it is referred to as a "prosocial" behaviour. As already noted, the term "prosociality" is used in experimental economics but also in other behavioral sciences to indicate a behavior that does not directly benefit others (as does cooperation), but the wellbeing of group interaction as a whole. ${ }^{15}$ The behavioral pattern of altruistic punishment has been clearly shown to be of great significance for the study of prosociality in a series of behavioral experiments in economics and neuroeconomics (Fehr and Gächter 2002; Fehr and Fischbacher 2003; Fehr and Rosenbach 2003; de Quervain et al. 2004). ${ }^{16}$ These have been conducted in different behavioral laboratories since the first study on altruistic punishment was published by Ernst Fehr and Simon Gächter (2002).

In this study, altruistic punishment is defined as a non-selfish act of punishment which "[provides] ... a material benefit for the future interaction partners of the punished subject but not for the punisher" (Fehr and Gächter 2002, p. 139). In an experimental setup with 240 participants ${ }^{17}$ at the University of Zurich, Fehr and Gächter tested their subject's individual willingness to punish altruistically in a "public goods" experiment. In this type of experiment, several people have the option of investing a certain amount of money in a group project. ${ }^{18}$ Afterwards, the sum of all contributions is to be shared among the group members equally. The

\footnotetext{
${ }^{12}$ The term "altruism" is used here in a behavioral sense referring to the outcomes and not the motivation behind this behavior. Thus, the economic use of the term has to be distinguished from its use in moral philosophy and psychology. See further discussion in Peacock et al. (2005); Clavien and Chapuisat (2013).

${ }^{13}$ Compare also Clavien and Klein (2010).

${ }^{14}$ The claim that social reciprocity (prosocial norm enforcement) provides the best explanation for the evolution of punishing behaviors has been defended in Carpenter et al. (2004).

${ }^{15} \mathrm{~A}$ definition of the distinction between prosociality and cooperation can be found in Henrich and Henrich (2006). For a model explaining the cultural evolution of prosociality and cooperation see Gintis (2003).

${ }^{16} \mathrm{An}$ assessment of the evolutionary origin of altruistic punishment can be found in Boyd et al. (2003).

${ }^{17}$ All of the participants in the experiment were undergraduate students from the University of Zurich.

${ }^{18}$ The money they earn is paid to them actually after the experiment.
} 
experiment in Zurich was conducted in 12 sessions and the group composition was changed after each session. The latter guaranteed that none of the subjects could again meet the same subjects during the experiment. This ensured that the subjects' decisions and behaviors were not based on a preference for reputation-building among group members. The opportunity to punish group members who did not invest in the group project, but benefited from its gain, was offered at the end of each session. In order to test whether the subjects' willingness to punish did include the willingness to suffer personal cost, the punishment was not only costly for the free rider, but also for the punishing subject himself, because he had to pay for it from his own gain.

The results of the experiment were as follows: over 12 sessions, the opportunity to punish social free-riding behavior was taken by $84.3 \%$ of the subjects at least once, and $34.3 \%$ of the subjects punished more than five times (Fehr and Gächter 2002 , p. 137). A minority of $9.3 \%$ of the subjects punished more than ten times. Thus, the experimental results provide strong evidence that altruistic punishment is a stable behavioral pattern among humans. Additionally, a significant effect of altruistic punishment was shown in the later sessions of the experiment. After having been punished, the punished subjects invested a higher amount of money in the group project and changed from non-cooperative to cooperative behaviors in the following sessions. Thus, altruistic punishment caused a substantial increase in terms of the average cooperation level of the group over time. This was highly correlated with the subject's investment strategies and can, therefore, be considered among the facilitating conditions of the evolution of human cooperation. Hence, the remarkable result of the study by Fehr and Gächter was that the opportunity to punish free riders altruistically has a significant impact on the maintenance of the norm of cooperation and equity, even in anonymous encounters.

With regard to the interpretation of this evidence, the researchers suggested that the evolution of social norms has to be explained further in terms of the level of the individual's preferences. Thus, they asked how the willingness to punish might be triggered on a psychological level. As a suggestion, it was hypothesized that the subjects' negative emotions concerning the free-riding behavior of others might be the source of their decision to punish. Emotions such as anger and outrage could provide a proximate mechanism of altruistic punishment. ${ }^{19}$

To elicit the correlation between punishment and the individual's emotions, the researchers prepared a questionnaire given to the subjects after the experiment that asked them to indicate their intensity of anger concerning the free-riding behavior on a seven-point scale. The results recorded that $47 \%$ of the subjects had indicated the highest intensity of anger. Hence, it was concluded that these emotions might be a psychological trigger for punishment. This led them to seek a research tool to further investigate this correlation, which in turn led them to engage in a new research field investigating the neurobiology of prosocial and cooperative behaviors in humans.

\footnotetext{
${ }^{19}$ A definition of proximate causes of evolution can be found in Mayr (1961, p. 1503).
} 
In a follow-up study (de Quervain et al. 2004, pp. 1254-8) to the first experiment on altruistic punishment in 2004, Fehr and fellow economist, Urs Fischbacher, started to work together with neuropsychologists for the first time. They added a neuroimaging tool to the experimental setup of their study on social norm enforcement and observed the neurological foundations of people's choices. The idea of combining experiments on norm enforcement with the neurological investigation of the human mind had already come up in a study in 2003 when neuroscientists Alan Sanfey, James Rilling and other colleagues had adapted an experimental design from economics, and started to investigate the neural substrates of the cognitive and emotional processes involved in decision making about altruistic punishment (Sanfey et al. 2003). After they brain-scanned the subjects with functional magnetic resonance imaging (fMRI), they found an increased activity in the "anterior insula"a brain area associated with negative emotional feelings. They concluded that emotions might be the psychological and neurological driving force behind this behavior, a view which was still consistent with the 2002 findings of Fehr and Gächter.

However, the follow-up study by Fehr, Fischbacher and de Quervain in 2004 led to a rather different neurological finding. The procedure of this experiment was as follows: the subjects were brain-scanned during their decision to punish free-riding behavior by using positron emission tomography (PET). They were placed in a scanner immediately after the interaction with another player was over. The scanning started when subjects learned about the free-riding behavior of the other participant and it finished when they had determined the punishment. In the observation of the neural circuits of the subjects' brains, it was shown that not the "interior insula" but a brain area linked to the anticipation of reward - the "caudate nucleus"played a prominent role when people decided to punish. Subjects who exhibited stronger activation of the "caudate nucleus" were ready to incur more personal costs to punish a free rider in comparison with subjects who exhibited low caudate activation.

Hence, the researchers interpreted the finding as evidence that the anticipation of "hedonic rewards" (de Quervain et al. 2004, p. 1257) was considered a benefit that altruistic punishers weighed against the costs of punishing. The punishing subjects seemed to feel relief when the violated social norm was established again through an act of retributive justice. Thus, it was concluded that, according to the underlying neurological processes, the subjects' decision-making was driven by hedonic motivation. Hedonic motivation is one of the key features in an evolutionary explanation of behavior, because there is natural selection for avoiding pain and unpleasantness. The correlation between hedonic motivation and altruistic punishment, then, might function as a proximate mechanism with respect to the evolution of human cooperation.

From the presentation and analysis of these pioneering experimental works it can be seen that the findings, in a way, renew the initial question of modern political philosophy posed by Thomas Hobbes (1651): How can human society with stable cooperation and norm enforcement evolve out of the nastiness and brutish 
character of the state of nature? At the same time this question is transformed in the laboratory setting of the neuroeconomic experiments by introducing a dual anthropology into this so-called "state of nature". It is no longer the question of how a society with stable cooperation and norm following can be built out of a bunch of egotistic individuals, but rather how it can evolve out of a group of egotistic and altruistic individuals interacting with each other. The interesting thing about this recent experimental research in neuroeconomics is, therefore, that it stimulates the perspective of a fighting antagonism between Homo economicus and Homo amans. This means, it regards the cooperative and prosocial orientation not just as a viable alternative which fully replaces the view that human beings are egotistic utility maximizers. Rather, prosociality is seen as an orientation that must establish and sustain itself in a direct confrontation with radically egotistic preferences and behaviors and can - under certain circumstances - be seen to prevail.

Experimental economists have examined in their research the individual conditions (of the human mind) and institutional factors (of setting and context) which can help altruism to win against egoism (Fehr and Fischbacher 2003, 2004, 2005). A combination of both perspectives, behavioral and neuroscientific, helps them to determine in more detail the nature of altruism and cooperative behaviors. What they discovered after extensive experimental research is that there is a mechanism in human brains which helps altruists and co-operators do their job. The experiments have therefore given an empirical proof that there actually exist altruists and co-operators which are willing to sacrifice their individual self-interest to safeguard the existence of common goods (such as social norms of fairness), and that they are naturally oriented towards the welfare and flourishing of society as whole.

What we can learn now from this research concerning a deeper understanding of the nature of love is the following: The modern romantic view that love is fully developed in an interpersonal relation is misleading. Instead, it can be argued from a Christian point of view, but also from the insights of recent experimental studies, that love has a prosocial nature insofar as it is reliant on introducing a third into the interpersonal relation and transforming it in the light of a universal signifier. Likewise, the view is false that love is always aiming at a personal benefit or at the welfare of others. Rather, it can require personal sacrifice or even loss of self and other in order to safeguard the welfare of society and its ethical virtues such as fairness, justice, and norm compliance. ${ }^{20}$

Further, what has been shown by Kierkegaard to be true for the inner struggle of love is also shown to be true in the neuroeconomic experiments for the outer dynamics of prosocial behavior: the significance of Homo amans, a human being with a preference for loving and cooperative behavior, lies in its potential for social transformation which, in the behavioral experiments, is manifest in the establishment and protection of social norms as a main public good of every society. Other orientations do not disappear when Homo amans, i.e. human beings with prosocial

\footnotetext{
${ }^{20}$ This reference to the virtue of institutions or society can be traced back to John Rawls (1971).
} 
preferences, appears on the scene. Hence, the Homo economicus has reality content as well, but - as the experiments have shown - the love for the third, the prosocial action, can definitely prevail due to its revolutionary nature. Thus, a convincing model of Homo amans and the nature of love should also provide a good analysis and explanation of the disruptive dynamic of love introducing a third that transgresses interpersonal relations.

\subsection{Conclusions}

Love is not a stable core of human nature nor a character trait that can be educated or trained. Rather, it should be seen as a dynamic structure at work in human attitudes and behaviors, arising out of a change of perspective concerning the world, oneself, and others. This change of perspective cannot be determined but happens for contingent reasons. This makes it uncomfortable to account for it in the realm of hard sciences with its focus on the measurability of love and cooperative behaviors. As has been shown, the characteristic of the dynamic structure of love is that it is creative in its nature because it brings into being a wholly new social reality, which transforms the status quo and the shape of human relationality completely by introducing a horizon of universality. Crucial for the prevalence of love in its true nature is the introduction of a notion of the third that opens the space for prosocial action and sets the focus on the welfare of all humankind or society as a whole.

Hence, it could be fruitful in future to explore in more detail the revolutionary potential of love - love's potential to induce social transformation and the role it plays in the implementation of radically new perspectives and social practices in human life. As has been further shown, the orientation of love is an orientation towards the third in the relationship with the other. Thus, it can be seen as structurally equal to what Kierkegaard already described in the language of Christian faith as the central dynamic of love of neighbor. The interpersonal relationship, which can be of a cooperative or non-cooperative nature, is transformed through love by introducing a third - in the experiments represented by a universal social norm of fairness and in the Christian faith represented by the universal perception of humans as children of God. Both orientations have in common that they describe the two terms "love of neighbor" and "prosociality" as revolutionary, i.e. disruptive dynamics which transgress the current social state and open it for a human sociality of a different kind. It inaugurates the existence of universal norms (in the horizon of a new and yet invisible social order) and overcomes the unstructured interaction of atomized individuals. Thus, love can be seen to set up the rules by setting out the rules first. It distances current social practice, for example, of free riding and exploiting the common good, and introduces a new one. Suspending the reigning unwritten rules is in itself an act of non-conformity. Building new structures of interaction by setting the rules for it in a kind of violently nonconformist act is, thus, a crucial capability of love. 


\section{References}

Aristotle. 2014. Nicomachean Ethics. Transl. and ed. R. Crisp. New York: Cambridge University Press.

Bauman, Z. 2000. Liquid Modernity. Cambridge: Polity Press.

Bedorf, T. 2003. Dimensionen des Dritten: Sozialphilosophische Modelle zwischen Ethischem und Politischem. Munich: Fink.

Boyd, R., et al. 2003. The Evolution of Altruistic Punishment. Proceedings of the National Academy of Sciences of the United States of America 100 (6): 3531-3535.

Carpenter, J.P., et al. 2004. Why Punish? Social Reciprocity and the Enforcement of Prosocial Norms. Journal of Evolutionary Economics 14: 407-429.

Clavien, C., and R.A. Klein. 2010. Eager for Fairness or for Revenge? Psychological Altruism in Economics. Economics \& Philosophy 26: 267-290.

Clavien, C., and M. Chapuisat. 2013. Altruism Across Disciplines: One Word, Multiple Meanings. Biology and Philosophy 28: 125-140.

Critchley, S. 2012. Faith of the Faithless. Experiments in Political Theology. London: Verso.

de Quervain, D.J.-F., et al. 2004. The Neural Basis of Altruistic Punishment. Science 305: $1254-1258$.

"Ein mentales Training, um toleranter Weltbürger zu werden," Interview with Prof. Tania Singer, Director at the Max-Planck-Institute for Human Cognitive and Brain Sciences, 7. Oct. 2017. https://www.mpg.de/11514867/interview-singer-neue-meditationstechnik-fuer-empathie. Accessed 26 Aug 2019.

Evans, C.S. 2008. Can Love be Commanded? Kierkegaard's View of Neighbor Love. In Visions of Agapé: Problems and Possibilities in Human and Divine Love, ed. C.A. Boyd, 73-83. Aldershot: Ashgate.

Fehr, E., and U. Fischbacher. 2003. The Nature of Human Altruism. Nature 425: 785-791. 2004. Social Norms and Human Cooperation. Trends in Cognitive Sciences 8: 185-190. 2005. Human Altruism: Proximate Patterns and Evolutionary Origins. Analyse \& Kritik 27: 6-47.

Fehr, E., and S. Gächter. 2002. Altruistic Punishment in Humans. Nature 415: 137-140.

Fehr, E., and B. Rosenbach. 2003. Detrimental Effects of Sanctions on Human Altruism. Nature 422: $137-140$.

Fowers, B.J. 2017. Frailty, Suffering, and Vice: Flourishing in the Face of Human Limitations. Washington, DC: American Psychological Association.

Gintis, H. 2000. Beyond Homo economicus: Evidence from Experimental Economics. Ecological Economics 35: 311-322.

2003. Solving the Puzzle of Prosociality. Rationality and Society 15: 155-187.

Glimcher, P.W., et al. 2009. Neuroeconomics: Decision-Making and the Brain. Amsterdam: Elsevier/Academic Press.

Grøn, A. 1998. Kierkegaards 'zweite’ Ethik. Transl. H. Schmid. In Kierkegaard Studies Yearbook 1998, ed. N.J. Cappelørn and H. Deuser, 358-368. Berlin: De Gruyter.

Hirsch-Hadorn, G., et al. 2008. The Emergence of Transdisciplinarity as a Form of Research. In Handbook of Transdisciplinarity Research, ed. G. Hirsch-Hadorn, 19-39. Frankfurt a.M.: Springer.

Hobbes, T. 1651. Leviathan, or, The Matter, Form and Power of A Common-Wealth Ecclesiastical and Civil. London: Printed for Andre Crooke.

Henrich, J., and N. Henrich. 2006. Culture, Evolution and the Puzzle of Human Cooperation. Cognitive Systems Research 7: 220-245.

Keyes, C., and J. Haidt, eds. 2007. Flourishing: Positive Psychology and the Life Well-Lived. Washington, DC: American Psychological Association. 
Kierkegaard, S. 1995. Works of Love: Some Christian Reflections in the Form of Discourses, Kierkegaard's Writings 16. Ed. and transl. H. V. Hong and E. H. Hong. Princeton: Princeton University Press.

Klein, R.A. 2011. Sociality as the Human Condition: Anthropology in Economic, Philosophical and Theological Perspective. Leiden: Brill.

2012. The Neurobiology of Altruistic Punishment: A Moral Assessment of its Social Utility. In Philosophy of Behavioral Biology, ed. K. Plaisance and T. Reydon, 297-313. Dordrecht: Springer.

— 2017. Theologie als transdisziplinäres Wissen: Wissenschaftliche Reformimpulse im Diskurs reformatorischen Denkens. Evangelische Theologie 77 (6): 437-450.

Krishek, S. 2017. Love as the End of Human Existence. In Kierkegaard's God and the Good Life, ed. S. Minister, J.A. Simmons, and M. Strawser, 3-15. Bloomington: Indiana University Press.

Lippitt, J. 2013. Kierkegaard and the Problem of Self-Love. Cambridge: Cambridge University Press. 2017. Kierkegaard's Virtues? Humility and Gratitude as the Grounds of Contentment, Patience, and Hope in Kierkegaard's Moral Psychology. In Kierkegaard's God and the Good Life, ed. S. Minister, J.A. Simmons, and M. Strawser, 95-113. Bloomington: Indiana University Press.

Mayr, E. 1961. Cause and Effect in Biology. Science 134: 1501-1506.

Mittelstraß, J. 1982. Wissenschaft als Lebensform. Reden über die philosophische Orientierung in Wissenschaft und Universität. Frankfurt a.M.: Suhrkamp.

—. 2003. Transdisziplinarität. Wissenschaftliche Zukunft und institutionelle Wirklichkeit. Konstanz: Universitätsverlag Konstanz.

Nowotny, H. 1997. Transdisziplinäre Wissensproduktion: Eine Antwort auf die Wissensexplosion? In Wissenschaft als Kultur: Österreichs Beitrag zur Moderne, ed. F. Stadler, 177-195. Vienna: Springer.

- 1999. The Place of People in Our Knowledge. European Review 7: 247-262.

Nowotny, H., P. Scott, and M. Gibbons. 2001. Re-Thinking Science: Knowledge and the Public in an Age of Uncertainty. Cambridge: Polity Press.

Peacock, M.S., et al. 2005. Altruism and the Indispensability of Motives. Analyse \& Kritik 27: 188-196.

Peitz, D. 2019, June 3. Macht menschlich! DIE ZEIT. https://www.zeit.de/kultur/2019-06/spdandrea-nahles-ruecktritt-machtkampf-parteivorstand. Accessed 9 Aug 2019.

Rawls, J. 1971. A Theory of Justice. Cambridge, MA: Belknap Press.

Roberts, R.C. 1995. Kierkegaard, Wittgenstein and the Method of 'Virtue Ethics'. In Kierkegaard in Post/Modernity, ed. M. Matustik and M. Westphal, 142-166. Bloomington: Indiana University Press.

—. 2008. Kierkegaard and Ethical Theory. In Ethics, Love and Faith in Kierkegaard, ed. M. Westphal, 72-92. Bloomington: Indiana University Press.

Sanfey, A.G., et al. 2003. The Neural Basis of Economic Decision-Making in the Ultimatum Game. Science 300: 1755-1758.

Schnelle, U. ${ }^{3} 1999$. Einleitung in das Neue Testament. Göttingen: Vandenhoeck \& Ruprecht.

Veninga, J.E. 2018. Loving the Ones We See: Kierkegaard's Neighbor-Love and the Politics of Pluralism. In Kierkegaard and Political Theology, ed. R. Sirvent and S. Morgan, 105-126. Eugene: Pickwick.

Volf, M. 2015. Flourishing: Why We Need Religion in A Globalized World. New Haven: Yale University Press.

Vromen, J., and C. Marchionni, eds. 2019. Neuroeconomics, Vol. I-IV, Critical Concepts in the Social Sciences. London: Routledge.

Welz, C. 2007. How to Comprehend the Incomprehensible Love? Kierkegaard Research and Philosophy of Emotion. Kierkegaardiana 24: 261-286. 
Open Access This chapter is licensed under the terms of the Creative Commons Attribution 4.0 International License (http://creativecommons.org/licenses/by/4.0/), which permits use, sharing, adaptation, distribution and reproduction in any medium or format, as long as you give appropriate credit to the original author(s) and the source, provide a link to the Creative Commons license and indicate if changes were made.

The images or other third party material in this chapter are included in the chapter's Creative Commons license, unless indicated otherwise in a credit line to the material. If material is not included in the chapter's Creative Commons license and your intended use is not permitted by statutory regulation or exceeds the permitted use, you will need to obtain permission directly from the copyright holder. 